\title{
6. The Don and Helen New Zealand Election 2005: A media a-gender?
}

\begin{abstract}
The media uses the technique of framing to process and package information in order to make sense of the material and present a news 'story' which is accessible to the audience. International research reports demonstrate a consistent 'gendered' framing of media coverage. 'Gendering' refers to the highlighting of a person's gender, when this is not particularly relevant to the context. Usually gendering involves seeing the male as the norm, and the female as the remarkable. In terms of the media and politics, this gendering includes the under-representation of women politicians, an emphasis on their appearance, marital and maternal status, and personality rather than the policies and issues of debate. More recently, however, there is evidence that in some contexts the media is becoming less overtly biased in its representation of women politicians. While there are still many ways in which women are presented differently from their male counterparts, there is also some evidence that an emphasis on gender is initiated by the party campaigns rather than being a result of media agenda-setting.
\end{abstract}

HEATHER DEVERE and SHARYN GRAHAM DAVIES

AUT University

7 MEDIA uses the technique of framing to process and package information in order to make sense of the material and present a news 'story' which is accessible to the audience. International research reports demonstrate a consistent 'gendered' framing of media coverage. 'Gendering' refers to the highlighting of a person's gender, when this is not particularly relevant to the context. Usually gendering involves seeing the 


\section{CONTEMPORARY GENDER ISSUES}

male as the norm, and the female as the remarkable. In terms of the media and politics, this gendering includes the under-representation of women politicians, an emphasis on their appearance, marital and maternal status, and personality rather than the policies and issues of debate. More recently, however, there is evidence that in some contexts the media is becoming less overtly biased in its representation of women politicians. While there are still many ways in which women are presented differently from their male counterparts, there is also some evidence that an emphasis on gender is initiated by the party campaigns rather than being a result of media agenda-setting.

This article examines media coverage of the 2005 New Zealand general election campaign for evidence of gender framing, particularly in relation to the portrayal of the leaders of the two main parties, Helen Clark, the Labour Prime Minister, and Don Brash, the leader of the main opposition National Party. Election coverage on television and in the print media was monitored during the month-long campaign before the September election for comments related to gender. It was found that gender was placed on the media agenda only after this was raised as an issue by Don Brash during the campaign. We suggest that, while the more obvious examples of gendered reporting have diminished, especially when compared to the 1999 election, nevertheless the New Zealand media is still responsible for a gendered framing of the leaders in the coverage of the 2005 election.

\section{The (In) Visible Women}

As a general statement, the evidence internationally is that women have been represented less in the media than men, and, more specifically, women politicians have been given less coverage than their male counterparts. In 1995 the Global Media Monitoring Project surveyed 70 countries and found that women amounted to only 17 percent of news subjects. By 2000 this had increased by only 1 percent (Gallagher 2004, p.148). The literature on media election reporting has noted that there has been relatively little coverage of women candidates and politicians of any party when compared to coverage of men. Research by the University of Loughborough, for example, reported in 1992 that the invisibility of women politicians was 'highly disconcerting' (Ross, 2002, p. 154). This is confirmed by Ross's more recent work which found that, even when incumbent politicians were considered, 'their visibility as spokespeople for the Government or the opposition is still minimal' (Ross, 2002, p. 154). 
Other research, however, suggests that the responsibility for the lack of visibility of women in the media lies with the political parties and in particular their campaign managers, rather than with the media. Lovenduski (2001), commenting on the British general election of 2001, argues that media reports on the invisibility of women in the national campaigns, mostly written by women journalists, caused embarrassment to campaign managers. Labour and the Liberal Democrats reacted quickly to the stories carried in the Guardian, The Times and the Independent about how few women were visible in the campaigns and suddenly, according to one observer, 'it was raining women' (Guardian, May 28, 2001, cited in Lovenduski, 2001, p. 184). Banwart, Bystrom, Robertson and Miller's (2003, p. 147) article on the 2000 election in the United States, comments that while many studies of media coverage of elections:

have documented that women and men are treated differently by the media... since the late 1990s, it has been shown that the media coverage of women and men candidates has become more equitable over time, particularly in terms of quantity.

Norris (1997) also claims that there is less evidence of gender role stereotyping in terms of appearance, traits or issues. This is confirmed by the results of the Second Global Media Monitoring Project conducted on 1 February 2000. According to this research, there was a 'marked reduction in simplistic, sensationalist and sexist coverage' of world women's conferences (Gallagher 2004, p. 154).

\section{The Little Women}

There is other evidence, though, that the media reporting of women politicians is still gendered. Banwart et al (2003, p. 147) also report that, while women are more visible than they used to be, other inequities have persisted in 'issue coverage' and women are more likely to be stereotyped as concerned only with 'feminine' issues. Sreberny-Mohammadi and Ross (1996, p. 116) argue that women politicians are more likely to be trivialised, and to be seen as 'diversions from the serious male game of politics'. Women candidates are often subjected to trivial comments about their appearance or are described using the diminutive. Research focusing on women running for legislative 


\section{CONTEMPORARY GENDER ISSUES}

office in Illinois, for example, cited one woman candidate as remarking that the media concentrated on 'stupid, little things such as clothes, hair etc' and described women by using loaded adjectives such as 'feisty, perky, small and lively' (Poole, cited in Ross 2002, p. 153). Ross (2002, p. 155) reports that during the 1997 British election, five women candidates were presented by the Evening Standard as 'the Spice Girls' and when 101 Labour women MPs were elected, they were immediately dubbed 'Blair's babes' by the media. Logan Fox (1997, p. 141) agrees 'that discrimination and traditional stereotyping still play a significant role in the experience of female candidates'. When Elizabeth Dole made a bid for the Republican presidential nomination in 1999, Heldman, Carroll and Olson (2005, p. 315) report that journalists:

focussed on her gender more than any other aspect of her candidacy, suggesting implicitly, if not explicitly, that she was a novelty in the race rather than a strong contender with a good chance of winning.

\section{The Wives and Mothers}

Personalisation is part of the media framing of political actors (Johnson-Carte 2005). For women the focus on their status as wives and mothers is often paramount. Jamieson (cited in Fountaine 2002, p. 16) notes that when Janet Reno was the United States Attorney General it was considered that she would not automatically pass the femininity test, because she was unmarried with no children and so 'familial affections' had to be 'certified in other ways for her' to ensure that she was seen to have the essential sensitive feminine characteristics. On the other hand, women who enter politics are sometimes portrayed as abandoning their children. For example, Australian politician Janine Haines (1992, p. 179) writes about a woman candidate who was told that women with children should not be in politics. In the 2001 British elections, according to Ross (2002, p. 153), women candidates typically commented about the high number of references made to their families in the media coverage, with one women stating that 'my identity was always associated with my husband'.

\section{The Femo-Nazis}

The term 'femo-nazi' is part of an anti-elitist discourse, which has in particular been applied to successful women bureaucrats or 'femocrats'. ${ }^{1}$ American research by Lind and Salo (2002) demonstrate that feminists are often 
demonised by the media, shown in a personalised and trivialised fashion, and portrayed as being different to 'regular' women. If women politicians do not fit the image of weak and feminine, or good wives and mothers, they are then represented as being inappropriately aggressive and masculine. Trent and Friedenberg (2004, p. 166) summarise more than 30 empirical investigations in 16 languages on political campaign communication and report that:

traditional expectations regarding the communication behaviour of men include characteristics such as strength, ambition, aggressiveness, independence, stoicism and rationality. However, the expectation for the communication behaviour of women is almost exactly a polar opposite. When women speak, they are expected to exhibit characteristics such as sensitivity to the needs of others, concern for family and relationships, compassion, emotionality, affection and nurturing.

Gidengil \& Everitt's claim that their findings from research into news coverage of the 1993 Canadian leaders' debates demonstrate 'that what is perceived - positively - to be combative in a man, may be judged — negativelyto be aggressive in a woman' (cited in Fountaine, 2000, p. 2).

The fact that the media narratives and framing of elections often use metaphors relating to competitions, horse-races, war and fighting puts women at a disadvantage (see for example, Johnson-Cartee, 2005). As linguist Deborah Tanner suggests:

Everything she does to enhance her assertiveness risks undercutting her femininity, in the eyes of others. And everything she does to fit expectations of how a woman should talk risks undercutting the impression of competence she makes (cited in Trent and Friedenberg, 2004).

Paletz (1996, p. 220) claims that in the gendered discourse of the media, the term feminist is equated with non-femininity. This, van Zoonen (cited in Paletz) argues, creates a division between 'ordinary women' and feminists, with women feminist politicians then being portrayed as unable to represent women generally. Comstock and Scharrer $(2005$, p. 245) agree and refer to Signorielli's research which points to 'a strict divide' in media coverage between 'female characters who are shown with marriage and family and the single, working women, providing limited models for success at combining 


\section{CONTEMPORARY GENDER ISSUES}

the mixed elements of many modern women's lives'.

\section{The Horse Race or the Cat Fight}

As Trimble \& Samper (2004, p. 54) point out, the framing of the election as a competitive game 'is enthusiastically employed by all news media when covering political events such as election campaigns, for it meets key elements of newsworthiness, offering conflict between elites, winners and losers, personalities, drama and immediacy'. The horse-race frame, according to Johnson-Cartee (2005), is used by the media in election reporting with constant reference to who is in the lead, laying bets on who will win or lose.

Kahn, in her 1994 study of American Senate candidates, argued that the media deliberately chose to frame the campaigns of women candidates differently from those of the men and found, for example, that "more time was devoted to the "horse race" element of women candidates than to their policy positions and more time was spent discussing negative "horse race" elements than was the case with male candidates' (cited in Ross, 2002, p. 156). Ross (2002, p. 152) argues that, while in a straight fight between a woman and a man, the campaign messages of the women politician are downplayed, 'there is some evidence to suggest that, in contests which pitch women against each other, news reports take on a rather different complexion'. She cites research by Braden during the 1992 New York State primaries when Elizabeth Holtzman and Geraldine Ferraro were 'portrayed as sisters attacking each other'. Alyson Cole (1999, p. 111) writing about 'sisterly squabbles' within feminism warns that the media is 'always happy to provide a stage for a good cat fight, and what better spectacle than feminist vitriol...'

\section{New Zealand media, elections and gender}

New Zealand has long been at the forefront of advances for women politically. New Zealand women were the first to gain national suffrage in 1893. Before the change to the Mixed Member Proportional (MMP) system, ${ }^{2}$ women were more highly represented than in any other first-past-the-post elected parliamentary system, and women have been cabinet ministers regularly since the 1970s. In 1999 New Zealand also became the first country where women were the leaders of both of the major parties contesting a national election (see for example, Banducci, 2002, p. 50).

The New Zealand media has, in general, followed the international trends 
of reporting on women and politics, although there have been some differences. In a survey of broadcasting news in New Zealand between 1985 and 1994, McGregor and Comrie (1995, p. 54) report that 'the gender of sources used in news stories was overwhelmingly male at 67 percent male, 16.1 percent female and 16.9 percent unknown'. When taking into account the subject matter of the stories, they found that 'politics was the most male-dominated in terms of sourcing with 87 percent male sources and only 13 percent of sources in political stories being female' (McGregor \& Comrie, 1995, p. 55). However, when compared to other countries, New Zealand measured up well. The Second Global Media Monitoring Project (cited in Fountaine 2002, p. 244) which monitored the media coverage of women on 1 February 2001 ranked New Zealand first out of the 70 countries surveyed in terms of the percentage of women used as sources in the political news, and a long way in front of the United States, Australia and the United Kingdom. ${ }^{3}$

While women have been more visible in the New Zealand media than women in other countries, there is nevertheless evidence of what McGregor (1996) and Comrie (2005) refer to as 'media misogyny' within New Zealand. McGregor (p. 185) reports on the response of political journalists to women politicians and claims that:

Because the gendered ideal of a Beehive Bimbo-Boadicea eludes political journalism, the response of the news media is to systematically trash female members of Parliament, party leaders and Cabinet Ministers while consistently ignoring the physical attributes of their male counterparts.

The reporting on Helen Clark, current Prime Minister of New Zealand, has included constant reference to her appearance and her childlessness. She is also often portrayed as unfeminine, arrogant and insensitive. Helen Clark was appealing to the media in 1989 to 'focus on my hard work, not my haircut' (cited in McGregor 1996, p. 183). When she took over as leader of the Labour Party in 1993, she was portrayed as the 'awful woman who had pushed a nice bloke out of the way' (McGregor, 1996, p. 190). On talkback radio she was referred to as the 'Dragon Lady' and 'Darth Vader in drag', by the host MP John Banks (McGregor, 1996, p. 184). Furthermore, award-winning journalist for North and South Lauren Quaintance in 2001 expressed surprise that 


\section{CONTEMPORARY GENDER ISSUES}

such a dry intellectual and, 'it must be said, childless woman, related to the people she stopped and spoke with' (cited in Fountaine 2002, p. 244).

\section{The Jenny and Helen Election 1999}

The 1999 New Zealand general election was the first time two women were vying for the position of Prime Minister. Helen Clark, then Leader of the Opposition Labour Party was campaigning against the National Party's Jenny Shipley, incumbent Prime Minister of New Zealand. Banducci (2002, p.50) claims that there was a 'lack of media focus on the novelty of the election being contested by two women'. While the campaigns of the two parties revolved around the party leaders she suggests that 'very little of either party's rhetoric focused on women' (Banducci, 2002, p. 51). Neither of the party leaders tried to present themselves particularly as champions of women's causes. Women were instead primarily portrayed as being part of a family, and families featured prominently in the broadcast campaigns.

Fountaine (2000) whose $\mathrm{PhD}$ research was on the 1999 election, reports that the media coverage of the campaign employed the usual 'political game frame' that is applied to most elections, despite the unusual element of having two women competing for the leadership of the country. So the language of war, games and competition, with boxing, horse racing and battle metaphors were used. The two women were described as being engaged in a 'direct contest', about 'even on points', but neither able initially to score 'a knockout blow'. (Fountaine, 2000, p. 3). It appeared, however, that the commentators and the media were 'disappointed that the women had been so wellbehaved'. The gendering of the fighting motif was attempted, even when there was no evidence of overt competitive behaviour. For example, the Sunday News reported that 'Clark kept her claws in, opting to avoid the cat fight expected of the two women leaders'.

There were some other 'gendered' sub-themes evident, in particular focussing on appearance and motherhood. For example, Helen Bain of the Dominion reported as follows:

The difference appearance can make was apparent in Parliament's adjournment debate last month. Mrs Shipley was radiant in a stunning new cobalt blue suit, while Miss Clark was drab in olive. Miss Clark's speech was well-focused, strong on content and confidently delivered, 
but it was the visual impression left by Mrs Shipley on the television news that was more striking (1999, November 9, p. 9).

By referring to them as 'Mrs' Shipley and 'Miss' Clark, Bain also draws attention to the difference between these two married women, with Jenny Shipley's married status being emphasised and Helen Clark being referred to as if she were single. ${ }^{4}$ The wife and motherhood theme was played out regularly in the media. According to Banducci (2002, p. 51):

Shipley tried to steer the debate toward motherhood. She attempted to distinguish herself from the childless Clark during the National Party broadcast with her often quoted line: 'I'm a politician... but I'm also a mum'.

The media was willing to pick up on what was a deliberate part of the National Party campaign. A leaked memo from the National Party's women's vice-president to party members had recommended that Shipley's mother role should be contrasted with Clark's lack of children (Fountaine, 2000, p. 15). Jenny Shipley, often accompanied by her husband, Burton, made constant reference to her own children, as for example, telling reporters that her children had bestowed the name 'Lipstick One' on her campaign bus (Fountaine, 2000, p.14). On the other hand, there were only two articles which mentioned Helen Clark's husband (referred to as 'her partner') and the main references to Clark's family 'were related to her childlessness' (Fountaine, 2000, p. 14).

\section{The Don and Helen Election 2005}

Atkinson (2003, p. 305) has vigorously criticised the media in New Zealand, arguing that since the deregulation of broadcasting in 1989, and the commercial convergence of the news media, serious journalism has 'languished'. However, during a panel discussion on the 2005 election, Atkinson judged the media coverage of the 2005 election to be 'much better'. He pointed to less intrusion by the media hosts in the broadcast debates, and claimed that the newspapers did a 'good job of elaborating policy'. On the other hand, he argued that the media had an 'obsession with Helen Clark as a control freak'. McLeay (2005) agreed, arguing that this was a gender issue as when male politicians exhibit leadership characteristics, they are portrayed as 'strong, 


\section{CONTEMPORARY GENDER ISSUES}

effective and authoritarian'. ${ }^{5}$

The early billboard advertisements which launched National's campaign in 2005 emphasised the contrast between Labour and National, with a split red and blue background, featuring head and shoulder images of Helen Clark and Don Brash, on separate sides, with a pithy slo-

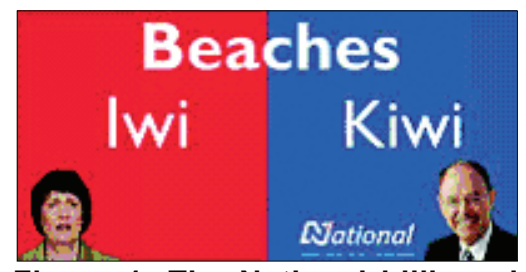

Figure 1: The National billboard advertisement.

gan, indicating some fundamental difference in approach. For example, the words 'iwi' (Maori for tribe) on the Labour side and 'Kiwi' on the National side represented the differences between the two parties on policy related to Maori and the Treaty of Waitangi, with National purporting to stand for 'mainstream' New Zealanders (Figure 1). This format characterised the campaign, with a focus once again on the two leaders, described by Phil Harris as the two major brands, the Brash versus Clark brands. ${ }^{6}$ Despite gender being an obvious key point of difference, however, there was initially no attempt in either the marketing campaigns or the media reporting to make any overt reference to this distinction, until the first televised leaders' debate.

On Monday, 22 August 2005, New Zealand's TV One aired a live leaders' debate between Helen Clark and Don Brash. During the debate Clark dominated the speaking time and spoke 13 percent more than Brash. As Clark herself said: 'I set out to dominate him and I'm happy I achieved that' (Young, 2005).

Following the debate, Brash commented:

I think it is not entirely appropriate for a man to aggressively attack a woman and I restrained myself for that reason. Had the other combatant been a man, my style might have been rather different (cited in Thomson \& Berry, 2005).

Brash's comments attracted a lot of attention, and this attention was not reduced when Brash tried to backtrack:

I don't think it's a good look for adults to shout and scream at each other. Particularly a bad look for men to be shouting at women. I think it gives a very bad example and I'm not interested in doing that (cited in Thomson \& Berry, 2005). 
Brash's remarks opened the way for a gender frame to be imposed on the campaign as the media seized the opportunity to present it as a contest between the courteous, chivalrous, slightly old-fashioned, but polite, gentlemanly Brash, and the strident, unladylike, aggressive 'rottweiler', feminist Clark. Questions were asked as to whether Brash could also be seen as patronising, sexist and chauvinist, but he did receive support for his restraint and good manners.

This debate dovetailed nicely with a long-standing media portrayal of Helen Clark as a domineering, unfeminine, arrogant control-freak, and the Labour Government as a social engineering, 'nanny state' ruled by a feminist cabal. Despite the fact that Helen Clark has been acknowledged as a superior debater, ${ }^{8}$ there is evidence that the qualities expected in a leader, such as assertiveness, ambition and strength, are perceived as inappropriate for a woman.

\section{Gentleman Don versus the Rottweiler}

Gentleman Don was given some praise in the media. The New Zealand Herald ran headlines such as 'Gentleman is not the same as chauvinist pig'. The Herald also quoted former National Party president Michelle Boag saying that 'people are trying to make something out of this just because the man is a gentleman' (cited in Beston, 2005). Boag continued: 'Don Brash is paying the price for being polite' (cited in Beston, 2005). The theme of Brash as a polite and gentle person was carried through into the editorials as well. A New Zealand Herald editorial (August 25, p. A14) remarked that Brash 'adheres to a code of good manners that has become sadly dated but can still be admired'. Two days later the Weekend Herald editorial (August 27, p. A22) noted:

Dr Brash might just be as chivalrous as he claims... but I think what makes him so different from other politicians is that he is perhaps too honest. He is polite, definitely, earnest, yes, but untainted by the cynicism displayed by the so-called experienced politicians.

Another media commentator suggested that politeness was being undermined because of 'this social engineering government' run by a very 'feminist Prime Minister' (cited in Berry, 2005). Moreover, the leader of the right-wing Act Party, Rodney Hide, called Don Brash a gentleman. The opportunity was 


\section{CONTEMPORARY GENDER ISSUES}

taken by Hide of making a comparison with Helen Clark as not being ladylike:

The Prime Minister didn't get to the top of the Labour Party and hold her position within the party by being ladylike. She is a tough, hardened political operator and the reality is Don Brash is a gentleman (cited in Thomson \& Berry, 2005).

Hide's argument seems to be that, while well-mannered, gentle men can become leaders, for a woman to get to the top, she has to be aggressive. By implication, therefore, if a woman is successful, then she will inevitably be an impolite, tough and manipulative leader. Among letters to the editor published on August 25 in a section of the New Zealand Herald entitled 'The Gender Agenda', the majority, 10 of the 14, were from men. There was only one which could be identified as from a woman. The other three writers used initials, so their gender could not be ascertained from their names. One reader commented that Brash was a gentleman who retained dignity while Clark was a hysterical harpy. Brash was seen by some as a nice and gentle person. Others saw him as trustworthy and polite, a man who made an effort to shake hands with journalists. Brash was seen as someone who would not shout you down.

However, Brash was also criticised as being out of date and out of touch with women. Auckland Debating Association president Wayne McDougall said Brash should have been concentrating on rebutting Clark's arguments, not on her gender. McDougall went on to say it would not have made any difference had Clark been a man - she was the superior debater and shut him out (cited in Thomson \& Berry, 2005). Green MP Metiria Turei said Brash's comments were, 'utterly pathetically sexist'. 'There is no way this guy could be our Prime Minister. He is an absolute outrage. He is ridiculously 19th century' (cited in Thomson \& Berry, 2005). Armstrong noted that by not regarding Clark as his equal in the leaders' debate Brash's remarks at best 'made him look like a politician from New Zealand's past'. 'At worst, he sounded patronising, condescending and sexist' (Armstrong, 2005). On the other hand, once again the contrast was drawn between Brash as mild-mannered and Clark as excessively aggressive, with Armstrong's rottweiler remark.

The idea that Brash's approach was too gentle to be effective against an aggressive attack from a woman was also covered in the media. John Roughan

76 PACIFIC JOURNALISM REVIEW 12 (1) 2006 
(2005) begins one of his columns singing the praises of Brash, noting that to succeed Brash would have had to 'raise the standard of politics [to his own high level] or lower his own'. Roughan goes on note that instead of ignoring Clark and concentrating on his own policy initiatives (e.g. lower taxes), Brash, 'listened to her, tried to answer, and she shut him out'. 'It wasn't pretty of her but it was effective' (Roughan, 2005). Roughan appears to believe that Brash genuinely does not realise how unfair and oppressive his attitude to and about women appears (Roughan, 2005). Roughan cannot decide whether Brash's innocence and lack of empathy makes these attitudes better or worse. One reading of this could be that Brash is just too nice and polite (which can be read as feminine qualities) for the aggressive, brutish (e.g. masculine) world of politics to which Clark is so suited.

Another commentator asked how Brash would be able to stand up against other strong powerful women, such as Condoleezza Rice, if he had trouble standing up to Clark (August 25, 2005). As one letter to the editor expressed it, 'Helluva choice - [ex-Prime Minister Robert] Muldoon in drag, or a flake who is too PC to tell a neurotic female to shut up. God save New Zealand' (Weekend Herald, Saturday, August 27, 2005, p. A22). In one cutting cartoon, Rob Emmerson (August 24, 2005) shows a peasant looking up at Don Brash who is mounted on a horse, dressed as a knight, and holding a lance and shield. Helen Clark is personified as the fire-breathing dragon. The peasant asks 'If you're not going to slay the dragon what are you planning to do?' Brash replies: 'Put her back in the kitchen where she belongs of course!'

Strength and determination in a woman are seen to equate with aggression and dogmatism. Helen Clark was said to have an inability to cope with and tolerate dissenting opinion (recorded in the editorial on August 24, p. A14). Clark was regarded as rude, arrogant, boring, and dogmatic (recorded in the editorial on August 24, p. A14). Clark received personal attacks, particularly during the leaders' debate where supporters of the National Party in the audience heckled her. When she raised her voice in order to be heard above the crowd, she received complaints for being too aggressive.

\section{Sexist Don versus Sexy Helen}

In accordance with the New Zealand media's tendency to personalise and trivialise election coverage, Prime TV screened an Election Special on Tuesday, August 30, 8.30pm, with Paul Holmes interviewing the leaders in their 


\section{CONTEMPORARY GENDER ISSUES}

homes, to see what we could learn about Clark and Brash from their marriages. The gendered theme this time framed Brash as old-fashioned and sexist, happy to be in a traditional and conservative marriage with a younger, passive and admiring wife. The gendered theme explored in Clark's relationship was whether Clark was sensitive and feminine enough to have a 'real' marriage.

Print media response to the relationship between Brash and his wife Je Lan were generally disparaging. For example, Jane Bowron, writing for the Dominion Post makes comments such as 'Je Lan snuggled in close on the couch to Don with the proximity bogan chicks award the male drivers of hot rods' and 'Je Lan stared at her husband with the rapt devotion of a Neil Diamond fan' (Bowron, 2005). In response to Je Lan's comment 'Now you know why I love him, because he's my number one fan', one journalist wrote that she could then suddenly hear the 'unmistakeable clatter of thousands of sensibly-hooved feminists as they sped across the bathroom lino to throw up in the loo' (Bowron, 2005). A comparison was made between the mild-mannered Je Lan and Helen Clark. 'No wonder Don found Helen's stentorian tones in the last leaders' debate a tad loud when all he's got to spar with at home is this reverential hush puppy' (Bowron, 2005).

Rosemary McLeod in the Sunday Star-Times also satirised the Holmes Election Special which she said portrayed Je Lan as a doting, passive Asian wife who lives only to please her chauvinistic husband and as a 'ministering angel to a male ego' (McLeod, 2005). McLeod remarked that she had not thought about National's plans for women until the documentary screened showing Je Lan sitting 'doll-like and adoring, on their beige sofa, where breadcrumbs and whiffy socks would never mar the marital serenity' (McLeod, 2005). Finally McLeod had grasped it - this is Brash's vision for all this country's women! Clutching her copy of The Female Eunuch, McLeod watched on horrified, observing Je Lan as a docile, pre-feminist, a 'wishful male fascist fantasy' (McLeod, 2005).

Clark's home life was also cross-examined. As McLeod noted: 'Helen Clark and her husband couldn't fail to look oddly normal, a pair of blokes who could be members of the same tramping club' (McLeod, 2005). One of the central issues of concern in the interview was Holmes' accusation that Clark and her husband, Peter Davis, have an 'ambiguous' marriage. This suggestion stemmed in no small part from last time Holmes visited their home and entered the marital bedroom to find twin beds (Bowron, 2005). It came as 
a welcome relief to Holmes, then, that a pair of 'his' and 'her' coffee mugs were produced to quell any anxiety people might have that there was anything ambiguous about the couple's relationship. But Holmes was persistent: 'Were you attracted to each other?' (Wichtel, 2005). Clark's partner is often characterised as a lap-dog carrying Clark's handbag and sheepishly following her and obeying her, and as being entirely overshadowed by her. Holmes, though, continually expressed surprise at the amount of talking Peter Davis did-'I have never seen him talk so much' (Sunday Star-Times, 2005). Holmes concluded that all was normal and that Clark 'was very sexy' and she 'was extra warm with Peter' (Sunday Star-Times, 2005).

\section{Summary}

In terms of the visibility and the framing of women, the New Zealand 2005 election demonstrates a number of trends. Since the 1996 election, the first time a woman was standing as leader of one of the major parties, ${ }^{9}$ there has been a consistent presence of a woman leader contesting the New Zealand elections, so women have remained visible. With the media concentrating on reporting elections as a 'horse-race' between the leading parties, it has thus been forced to pay attention to women politicians. New Zealand also compares well in research reporting on the use of women as sources in news stories, as the Global Media Monitoring Project indicates.

With women being the main players in the 1999 election, Helen Clark and Jenny Shipley could not be portrayed as mere diversions from the real game of politics. However, there was an emphasis on their physical appearance in particular, which is consistent with a continued attempt at trivialisation of women politicians by the media. In the 1999 election, the appearance of both women and what they were wearing was described in detail, and often used to contrast the different approach to fashion by the two leaders. While description of her attire was less in evidence in 2005, comments were being made in the media about the 'airbrushing' of Helen Clark's campaign photos, while much less was made about those of Don Brash. Paul Holmes' attempt to rescue Helen Clark from her non-feminine image by describing her as 'sexy' is another example of a patronising trivialisation of the election campaign.

In both 1999 and 2005, the politicians themselves tried to focus the debate on family rather than gender issues. But Jenny Shipley's motherhood status was emphasised by the National Party, and the media drew attention to Clark's childlessness. A similar emphasis on Don Brash as a father was not PACIFIC JOURNALISM REVIEW 12 (1) 200679 


\section{CONTEMPORARY GENDER ISSUES}

made in 2005 campaign, but the media continued to make reference to the fact that Helen Clark has no children. As Jamieson (in Fountaine 2002) suggests, childlessness in women needs to be countered in order for women's femininity and sensitivity to be certified. The subtext to references to Clark's lack of children is that she cannot understand the experience of other women, and therefore is out of touch. If she is perceived to be a feminist as well, there are suggestions that her marriage is a sham, and that she may be a lesbian. The irony is that one of the objections to women entering politics was based on the fear that they would be neglecting their children. When a woman chooses not to have children in order to focus on her political role, this is then seen as an indication that she lacks some kind of 'natural' maternal instinct.

Helen Clark has consistently been subjected to the gendered discourse of the media described by Paletz (1995) which equates feminism with non-femininity. While she successfully competes in the horse-race of election campaigning, she is portrayed as being overly aggressive, arrogant, and somewhat of a bully, especially in her relationship to men. When she took over leadership of the Labour Party, she was reviled for the way she treated Geoffrey Palmer and Mike Moore, the former leaders of the Labour Party. When she took on Don Brash in the leadership debates, she was portrayed as crass, tough and unladylike. When her police-conducted motorcade was stopped for speeding, she was portrayed as being unsupportive of her male drivers. ${ }^{10}$ When her marriage is examined, Peter Davis is portrayed as being hen-pecked and cowed. Even though Davis is a university professor and head of the Department of Sociology at Auckland University, Holmes appears surprised that he is able to voice his own opinions.

Don Brash was also subjected to a gendered framing by the media. While at times his hesitancy and mild manner is portrayed as weak and indecisive, on the other hand it is quickly reframed as being evidence of the behaviour of a polite and gentlemanly politician, and not as a threat to social order. In contrast, Clark, with her unlady-like voice and manner, is portrayed as a strident and domineering leader of a feminist cabal, part of an elite which is bent on social engineering. 


\section{Conclusion}

New Zealand compares well in terms of its representation of women in political positions and also the New Zealand media compares well in terms of using women sources in the political news. However, the New Zealand media continues to use a gendered framing in its reporting of politics. The gendered framing in politics is of concern for several reasons.

Framing of politics in the media and by the political parties establishes boundaries within which political issues are publicly discussed. If women politicians are criticised as being inadequate mothers or as having to abandon those characteristics and values associated with womanhood, then this reinforces the idea that politics is an unsuitable career for a woman. Women are still under-represented as politicians, and research continues to find that 'women are less likely to seek political office than similarly situated men' (Lawless \& Fox, 2005). In addition, the framing of successful women politicians as unlike and distant from ordinary women puts them out of touch with their constituents and portrays them as dangerous and unlikely to be acting in the interests of women who are not part of the select elite. This is itself part of a market populist discourse which is evident in much of the Western media. The work of Sawer and Hindess (2004), for example, explains how an 'us and them' dichotomy is constructed between the ordinary public and the controlling elite. Other commentators, such as Claudia Card (2006, p. 223), also suggest that the word feminist is used as 'the F word' to create 'a derogatory, scornful aura around a concept'. As Trimble \& Sampert (2004, p. 69) point out, electoral democracy is both trivialised and de-politicised 'by telling stories about the most superficial, episodic and tactical elements of the campaign'. When gender was placed on the political agenda of media coverage of the 2005 New Zealand election, this did not promote an opportunity to debate genuine issues of concern about gender differences, but instead seemed to give the media permission to trivialise the two leaders.

In the 21 st century, the media agenda-setting capacity has been countered to a large extent by spin-doctoring, as political parties and leaders attempt to ensure that the reporting of elections reflects the favourable image decided upon and managed by their own public relations team, in the battle to win the public opinion race. The more explicit sexism of media reporting is no longer as evident. However, although the overt gendered coverage of election campaigns has diminished, the issue of gender differences still emerged in the 2005 election campaign in New Zealand. 


\section{CONTEMPORARY GENDER ISSUES}

This gendered framing was not imposed on the campaign in any obvious way until the first leadership debate. Placing gender on the agenda could be attributed to Don Brash rather than the media. But from then on, the underlying structuring of the debate by the media took over. The framing of Helen Clark as strident feminist, with a sub-text relating to her childlessness and masculinity, marked her out as a strong, but dangerous leader. In her third term as Prime Minister, it is likely that this framing will continue. The question remains, however, whether this is part of a wider political agenda, or whether it is merely part of the media tradition of the portrayal of women.

\section{Notes}

1 See for example, Marian Sawer and Barry Hindess (Eds.) 2004 Us and Them: Anti-Elitism in Australia, APT Network.

2 MMP is a proportional voting system in which each voter has two votes. One vote is used to elect an electorate representative by first-past-the-post, and the other vote is used to elect the remaining Members of Parliament from party lists of candidates.

3 New Zealand: 46 percent women, 54 percent men; United States 18 percent women, 82 percent men; Australia 11 percent women, 89 pecent men, United Kingdom: 9 percent women, 91 percent men.

4 Helen Clark continues to use her maiden name, although she is married to Professor Peter Davis.

5 Dr Joe Atkinson and Dr Elizabeth McLeay took part in panels on the New Zealand 2005 Election and Political Leadership at the Australasian Political Studies Association Conference hosted by the Politics Department, Otago University, Dunedin, 28-30 September 2005.

6 Phil Harris was also part of the panel on Leadership at the APSA Conference, 2005, Dunedin.

7 Armstrong's article concluded when a 'rottweiler is biting your head off, pondering its gender would seem to be of rather secondary importance'. When Ruth Richardson was Minister of Finance in the National Government, there were also regular rottweiler jokes (see McGregor 1996, p. 183).

8 See for example, Wayne McDougall, Auckland Debating Association President's comments (cited in Thomson and Berry, 2005).

9 The year 1996 was also the first time an MMP election was held in New Zealand. Helen Clark, then leader of the Labour Party conceded the election to Jim Bolger of the National Party, after a coalition was agreed between National and New Zealand First, the latter party being led by Winston Peters.

10 Since the incident in 2004, this has been referred to constantly in the media, as 
an example of Helen Clark's high-handed attitude. A short profile of Helen Clark in the New Zealand Listener 2005 power list in November reports 'Clark's Achilles' heel is her perceived arrogance and bossiness, and her indifference to the speed of her motorcade as it raced through South Canterbury last year is constantly raised as an example' (Watkins 2005, p. 20). Helen Clark is placed at the top of the power list, and she and her husband Professor Peter Davis are the leading 'power pairing' in New Zealand (Watkins 2005, p. 32).

\section{References}

Armstrong, J. (2005). Don't worry about gender when rottweiler bites. New Zealand Herald, August 26, p. A3.

Atkinson, J. (2003). Tabloid democracy. In R. Miller (Ed.), New Zealand government and politics (3rd edn.) South Melbourne: Oxford University Press, pp. 305319.

Atkinson, J. (2005). Panel on the 2005 New Zealand election, Australasian Political Studies Association Conference, Dunedin, Sept. 28-30th.

Bain, H. (1999, November 9). Trying to look the part. Dominion, p. 9.

Banducci, S. (2002). Gender and leadership. In J. Vowles, P. Aimer, J. Karp, S. Banducci, R Miller \& A Sullivan (Eds.). Proportional representation on trial: The 1999 New Zealand general election and the fate of MMP. Auckland: Auckland University Press, pp. 50-65.

Banwart, M. C., Bystrom, D. G. , Robertson, T., \& Miller, J. (2003). Issue agenda in candidate messages versus media coverage: Are women and men on the same page? In L. L. Kaid, J. C. Tedesco, D. G. Bystrom \& M. S. McKinney (Eds.) The Millennium election: Communication in the 2000 campaign. Lantham/Boulder/New York/ Toronto/Oxford: Rowman and Littlefield.

Berry, R. (2005, August 25). Daughter gave Brash a lesson in equal rights. New Zealand Herald. p. A5.

Beston, A. (2005, August 27). Gentleman is not same as chauvinist pig. New Zealand Herald, p. A3.

Blucher, B. (2005, August 15). Letter to the editor. New Zealand Herald.

Bowron, J. (2005, September 1). What a pity all the party leaders and their partners didn't get a look in on Prime TV's Holmes: At home with Clark and Brash. Dominion Post.

Card, C. (2006). The L word and the F word. Hypatia, Spring, 21:2, pp. 223-229.

Comrie, M. (2005). Leadership and media, panel discussion at Australasian Political Studies Association Conference, Dunedin, September.

Fountaine, S. (2000). Women players: the game frame in the 1999 general election. Palmerston North: New Zealand Centre for Women and Leadership, College of Business, Massey University.

Fountaine, S. (2002). Are we there yet? The long road to gender equity in the news. In Judy McGregor and Margie Comrie (eds.), What's news: Reclaiming journalism in New Zealand. Palmerston North: Dunmore Press, pp. 244-258. 


\section{CONTEMPORARY GENDER ISSUES}

Gallagher, M. (2004). The impact of monitoring media images of women. In C. Carter and L. Steiner (Eds). Critical readings: Media and gender. Maidenhead: Open University Press.

Haines, J. (1992). Suffrage to sufferance: 100 years of women in politics. St. Leonards: Allen and Unwin.

Hope, W. (2003). Media and political process. In R Miller (Ed.), New Zealand government and politics (3rd edn.) South Melbourne: Oxford University Press, pp. 330-344.

Lawless, J. L. \& Fox, R. L. (2005). It takes a candidate: Why women don't run for office. Cambridge University Press.

Lind, R. A. \& Salo, C. (2002). The framing of feminists and feminism in news and public affairs programs in US electronic media. Journal of Communication. 52:1, pp.211-231.

Lovenduski, J. (2001). Women and politics: Minority representations or critical mass? In P. Norris (Ed.), Britain votes 2001. Oxford: Oxford University Press.

McGregor, J. (1996). Gender politics and the news: The search for a Beehive bimboBoadicea. In J McGregor (Ed.), Dangerous democracy? News media politics in New Zealand. Palmerston North: Dunmore Press, pp. 183-190.

McGregor, J. \& Comrie, M. (1995). Balance and fairness in broadcasting news $1985-$ 1994. Palmerston North: Massey University.

McLeay, E. (2005). Panel on the 2005 New Zealand election, Australasian Political Studies Association Conference, Dunedin, September 28-30.

McLeod, R. (2005, September 4). Brash's beige vision of women a cause for red alert. Sunday Star-Times, p. C9.

Niven, D. Z. (2001). 'How does she have time for kids and Congress?' Views on gender and media coverage from House offices. Women and Politics 23:1-2, Winter, pp. 147-166.

Norris, P. (1997). Women, media and politics. Oxford: Oxford University Press.

Paletz, D. L. ed. (1996). Political communication in action. Cresskill: Hampton Press. Phillips, A. (1991). Engendering democracy. Cambridge: Polity Press.

Prime Television. (2005, August 30). Holmes: At home with Clark and Brash. Auckland.

Ross, K. (2002). Women, politics, media: Uneasy relations in comparative perspective. Cresskill, New Jersey: Hampton Press.

Roughan, J. (2005, August 27). Brash: A Hero Set for a Fall. New Zealand Herald, p. A24.

Sawer, M. \& Hindess, B. (Eds.) (2004) Us and them: Anti-elitism in Australia. APINetwork.

Sunday Star-Times. (2005). 'Very sexy' PM casts spell on Holmes.

The Editors. (2005,A ugust 25). Our view: Fairness, not gender the issue. New Zealand Herald, p. A14.

Thomson, A. \& Berry, R. (2005, August 24). Gentleman Don affronted by sexist tag, The New Zealand Herald, p. A5.

Trent, J. S. \& Friedenberg, R. V. (2004). Political campaign communication: Prin-

84 PACIFIC JOURNALISM REVIEW 12 (1) 2006 
ciples and practices (5th edn). Lanham/Boulder/New York/Toronto/Oxford: Rowman and Littlefield.

Trimble, L. \& Sampert, S. (2004). Who's in the game? The framing of the Canadian election 2000 by The Globe and Mail and The National Post. Canadian Journal of Political Science, March 37:1, pp. 51-71.

Van Zoonen, L. (1996). A dance of death: New social movements and the mass media. In D.L. Paletz (Ed.), Political communication in action. Cresskill: Hampton Press.

Watkins, T. (2005, November 12-18). The 2005 power list. New Zealand Listener, pp. $20-32$.

Wichtel, D. (2005, August 25). Follow the leader. New Zealand Listener, p. A5.

Dr Heather Devere is senior lecturer in the School of Social Sciences at AUT University. Heather teaches politics, ethics and conflict resolution. Her research areas are women and politics, the philosophy of friendship and refugee resettlement. Heather has co-edited a book entitled The Challenge to Friendship in Modernity by Frank Cass of London, and has published in the Australian Journal of Political Science, ACCESS, Critical Review of International Social and Political Philosophy, Forced Migration Review and the New Zealand Journal of Media Studies.

heather.devere@aut.ac.nz

Dr Sharyn Graham Davies is senior lecturer in the School of Social Sciences at AUT University. Her research focuses on issues of women in politics and gender and sexuality in Indonesia. Sharyn has published in the Journal of Gender Studies, Journal of Bisexuality, Intersections: Gender, History and Culture in the Asian Context, and has forthcoming monograph publications with RoutledgeCurzon and Wadsworth/Thompson.

sdavies@aut.ac.nz 